\title{
IMPLEMENTASI MODEL PEMBELAJARAN KOOPERATIF TIPE TGT SEBAGAI UPAYA MENINGKATKAN PEMAHAMAN KONSEP FISIKA DASAR MAHASISWA PENDIDIKAN IPA
}

\author{
Astuti Wijayanti \\ Program Studi Pendidikan IPA FKIP Universitas Sarjanawiyata Tamansiswa, Yogyakarta \\ Email: astuti.wijayanti@ustjogja.ac.id
}

\begin{abstract}
Abstrak. Penelitian Tindakan Kelas (PTK) dilaksanakan di Prodi Pendidikan IPA UST untuk mengetahui peningkatan pemahaman konsep Fisika Dasar dan partisipasi mahasiswa Pendidikan IPA dengan menggunakan model pembelajaran TGT. Untuk mengamati proses pembelajaran dengan menggunakan model pembelajaran TGT digunakan lembar observasi mahasiswa dan dosen. Instrumen yang digunakan meliputi lembar observasi aktivitas dosen dan mahasiswa dalam kegiatan belajar tim dan lembar tes (postest). Hasil penelitian menunjukkan bahwa pembelajaran Fisika Dasar dengan menggunakan model pembelajaran kooperatif tipe TGT dapat meningkatkan pemahaman konsep dan partisipasi mahasiswa pendidikan IPA.
\end{abstract}

Kata Kunci: pemahaman konsep, partisipasi mahasiswa, model pembelajaran kooperatif tipe TGT

\begin{abstract}
Classroom Action Research held in Science Education UST to find an improved understanding of the concept of Basic Physics and Science Education student participation using TGT learning model. To observe the process of learning using TGT learning model used observation sheet of students and lecturers . Instruments used include observation sheet activities of faculty and students in learning activities team and a test sheet (posttest). The results showed that the learning Physics using cooperative learning model TGT can improve understanding of the concept and science education student participation.
\end{abstract}

Keywords : conceptual understanding, student participation, cooperative learning model TGT

\section{PENDAHULUAN}

Dari hasil observasi yang dilakukan di Prodi Pendidikan IPA, ditemukan beberapa permasalahan sebagai berikut: 1) Fisika dianggap sulit oleh sebagian besar mahasiswa sehingga mahasiswa kurang berminat terhadap mata kuliah Fisika Dasar; 2) rendahnya nilai rata-rata ulangan akhir semester yaitu sebesar 6,5 ; 3) Sistem pengajaran yang masih menekankan pada hafalan-hafalan sehingga mahasiswa lebih cepat bosan dan mudah lupa; 4) Pembelajaran dengan menggunakan presentasi membuat mahasiswa bergantung pada teman lain untuk mengerjakan; dan 5) Kendala lain yaitu adanya mahasiswa yang menemui kesulitan untuk memahami konsep yang telah disampaikan oleh dosen. Hal ini dikarenakan mereka kurang antusias untuk terlibat aktif dalam diskusi kelas. Dosen berusaha memberi kesempatan bagi semua mahasiswa yang ingin bertanya atau mengemukakan pendapatnya tetapi hanya mahasiswa tertentu saja yang berani bertanya dan berpendapat dalam pembelajaran.

Proses perkuliahan merupakan inti dari kegiatan pendidikan di universitas. Pembelajaran di dalam kelas yang bermutu tentu akan membuahkan hasil lebih baik. Dalam hal ini dosen memiliki peran yang sangat besar dalam menentukan kualitas pembelajaran yaitu terutama dalam mengorganisasi kelas sebagai bagian dari proses pembelajaran dan mahasiswa sebagai subyek yang sedang belajar. Peran dosen yaitu mengelola proses pembelajaran di kelas dengan menitikberatkan pada aktivitas mahasiswa. Pengelolaan kelas ditujukan pada kegiatan-kegiatan yang dilakukan oleh dosen dengan tujuan untuk menciptakan dan mempertahankan kondisi optimal di dalam kelas bagi berlangsungnya proses pembelajaran yang efektif.

Upaya untuk mengatasi masalah di atas yaitu dosen dapat mengimplementasikan model pembelajaran yang mampu mengkonstruksi pengetahuan mahasiswa. Inovasi pembelajaran seperti ini akan mengubah paradigma lama menjadi paradigma baru dimana pendekatan pembelajaran dapat mengembangkan dan menggali pengetahuan mahasiswa secara konkrit dan mandiri, terutama dalam menggali pengetahuan pada mata kuliah Fisika Dasar. Model pembelajaran yang dapat diterapkan untuk mengatasi masalah di kelas pendidikan IPA yaitu pembelajaran kooperatif.

Pembelajaran kooperatif merupakan pembelajaran yang berorientasi pada mahasiswa. Mahasiswa belajar dalam kelompok-kelompok kecil. Di dalam pembelajaran kooperatif (Cooperative Learning) tidak hanya mempelajari materi saja, namun mahasiswa juga mempelajari keterampilanketerampilan khusus yang disebut keterampilan kooperatif. Keterampilan kooperatif ini berfungsi untuk melancarkan hubungan kerja dan tugas. Peranan hubungan kerja dapat dibangun melalui komunikasi antar anggota kelompok. Sedangkan peranan tugas dilakukan dengan pembagian tugas antar anggota kelompok selama kegiatan. Kelebihan dalam pembelajaran kooperatif yaitu mahasiswa bisa saling membantu dan berdiskusi bersama-sama dalam menyelesaikan kegiatan belajar [1,2].

Hasil penelitian terdahulu menunjukkan bahwa pembelajaran kooperatif dapat meningkatkan 
hasil belajar dan pemahaman kosep siswa [3-8]. Berdasarkan hal tersebut maka dalam penelitian ini, penulis berharap dapat: 1) mengetahui bagaimana proses pembelajaran dengan menggunakan model pembelajaran TGT dalam meningkatkan pemahaman konsep mahasiswa; 2) mengetahui bagaimana TGT dapat membuat mahasiswa berpartisipasi, lebih percaya diri dan berfikir dengan sungguh-sungguh dalam turnamen ini; dan 3) mengetahui peran pembawa kartu untuk keberhasilan kelompoknya.

\section{METODE PENELITIAN}

Subjek penelitian ini adalah mahasiswa Prodi Pendidikan IPA semester gasal FKIP UST, dengan jumlah siswa 31 orang. Metode pengambilan data dalam penelitian ini adalah dengan metode tes, dan metode observasi. Metode tes digunakan untuk mendapatkan data hasil pemahaman konsep fisika dasar mahasiswa, dan metode observasi digunakan untuk memperoleh data tentang kegiatan selama dosen dan mahasiswa melakukan TGT.

Penelitian ini dilakukan dengan desain seperti yang biasa dilakukan pada penelitian tindakan kelas, yaitu melalui tahap-tahap (1) perencanaan, (2) implementasi, (3) observasi, (4) refleksi yang dilaksanakan secara bersiklus. Tahap-tahap kegiatan ini terus berulang sampai sesuatu permasalahan dianggap teratasi. Setiap akhir siklus dilakukan refleksi untuk menentukan keberhasilan tindakan dan melakukan perbaikan untuk tindakan selanjutnya. Banyak sedikitnya jumlah siklus dalam Penelitian Tindakan Kelas (PTK) bergantung pada terselesaikannya masalah yang diteliti. Ada suatu penelitian yang cukup dilakukan dalam dua siklus, karena masalahnya dapat terselesaikan namun ada juga yang memerlukan/melalui beberapa siklus.

\section{HASIL PENELITIAN DAN PEMBAHASAN}

\section{Hasil Penelitian}

Setiap siklus pada penelitian ini diawali dengan pelaksanaan pembelajaran dengan pembahasan materi, presentasi, penugasan dan diskusi kelompok. Hal ini diperlukan untuk mengkompakkan kelompok diskusi dalam memahami materi yang sedang dipelajari. Penelitian ini dilaksanakan dalam dua siklus. Setiap siklusnya menggunakan model pembelajaran TGT dengan materi pokok fisika dasar yang berbeda. Kegiatan observasi dilakukan peneliti dan observer untuk mengetahui aktivitas dosen dan mahasiswa selama model pembelajaran TGT berlangsung dan mengetahui semua kejadian-kejadian yang terjadi dalam pembelajaran tersebut. Adanya indikasi belajar bermakna diungkap dari analisis hasil perolehan kartu dari tiap pembawa kartu, dan tes yang dilaksanakan di akhir pembelajaran (post test). Hasil penelitian dan pembahasan akan disajikan dalam setiap siklus agar lebih jelas dan mudah dipahami.

\section{1) Perencanaan}

Pada siklus pertama, pembelajaran berlangsung selama empat kali pertemuan. Kegiatan penelitian siklus pertama ini membahas dan mereview materi yang diajarkan meliputi usaha energi dan impuls momentum. Skenario tindakan siklus I disajikan sebagai berikut :

Dosen mengiformasikan kepada mahasiswa tentang pembelajaran yang akan dilaksanakan selama tatap muka. Pada pertemuan pertama sampai pertemuan ketiga, mahasiswa dikelompokkan menjadi lima kelompok diskusi yang beranggotakan setiap kelompok sebanyak enam sampai dengan tujuh orang. Kelompok diskusi disusun oleh dosen berdasarkan kemampuan dan jenis kelamin. Setiap kelompok diharapkan melakukan dan mengerjakan tugas yang diberikan dosen sesuai waktu yang telah ditetapkan. Setiap kelompok diberikan bahan diskusi dan soal tugas kelompok. Pada ketiga pertemuan tersebut dilakukan pembahasan materi dengan diskusi dan latihan soal serta praktikum. Pada pertemuan keempat, Dosen mengiformasikan langkah-langkah pembelajaran TGT yaitu team, games, dan turnamen. Kegiatan TGT ini memberikan kesempatan kepada mahasiswa untuk melakukan permainan dan kompetisi [9]

\section{2) Pelaksanaan Tindakan}

Berdasarkan hasil pengamatan observer, dosen secara umum telah melaksanakan langkahlangkah pembelajaran TGT sesuai yang direncanakan. Dosen menyusun kelompok baru dari perwakilan kelompok diskusi untuk menempati meja turnamen. Kelompok pada masing-masing meja turnamen memiliki pengetahuan akademik yang hampir sama, meja turnamen 1 - 2 dengan prestasi akademik tinggi, meja turnamen 3-4 dengan prestasi akademik sedang, dan meja turnamen 5-6 dengan prestasi akademik rendah. Dosen menyediakan kartu soal dan jawaban yang digunakan dalam pembelajaran. Hasil pengamatan observasi, dosen agak kesulitan membimbing kelompok karena kelompok meja turnamen belum dapat melaksanakan peraturan yang telah disepakati dengan baik.

Mahasiswa diharapkan mampu mengingat dan memahami konsep yang telah dipelajari. Untuk membantu peningkatan pemahaman konsep, selain dengan kegiatan praktik pada pertemuan sebelumnya maka upaya peningkatan pemahaman konsep juga dilakukan dengan permainan dalam rangka mereview materi yang telah diajarkan. Hasil pemahaman konsep yang telah diperoleh melalui beberapa pertemuan dengan cara diskusi, kemudian dikaitkan dengan contoh-contoh dalam lingkungan. Mahasiswa telah menyampaikan kejadian atau peristiwa dan memberikan penjelasan yang berkait konsep yang telah mereka peroleh. Selain itu mahasiswa mendiskusikan pemecahan soal yang berkaitan

Pelaksanaan Penelitian Siklus 1 
dengan penggunaan prinsip-prinsip maupun rumusrumus dalam soal-soal.

\section{3) Hasil Observasi/ Monitoring Tindakan}

\section{a) Aktivitas Dosen}

Secara umum pelaksanaan pembelajaran yang dilakukan oleh dosen pada pelaksanaan TGT berdasarkan pengamatan telah berjalan sesuai langkah-langkah yang direncanakan. Aktivitas dosen dalam pembelajaran TGT menunjukkan bahwa prosedur/ langkah-langkah pembelajaran telah berjalan sesuai yang direncanakan. Hasil catatan jurnal dosen dan catatan kolaborator, mahasiswa sebagian besar masih merasa kesulitan dalam hal melaksanakan kesepakatan peraturan dalam pembelajaran TGT. Selain itu menurut pengamatan kolaborator dosen sudah berusaha memberikan informasi dan penjelasan tentang peraturan yang telah disepakati dalam TGT. Dosen telah memberikan arahan agar tiap perwakilan kembali ke kelompok awal dengan membawa hasil perolehan kartu tetapi dosen belum memberikan penjelasan pada kelompok yang terlambat dalam menyelesaikan TGT.

\section{b) Aktivitas Mahasiswa}

Hasil pengamatan terhadap aktivitas mahasiswa dalam pembelajaran mahasiswa telah melakukan prosedur pembelajaran TGT sesuai yang direncanakan. Menurut catatan jurnal dosen dan catatan dari kolaborator secara umum mahasiswa telah melaksanakan tahapan-tahapan TGT secara sungguh-sungguh. Dari pengamatan masih dijumpai kecepatan menyelesaikan permainan TGT tidak sama. Hal ini terjadi adanya kelompok yang bermain dan berdiskusi secara mendalam dan serius dalam menyelesaikan 20 soal permainan. Selain itu juga dijumpai meja turnamen yang masih kebingungan dalam penentuan yang berhak menjadi "reader"/pembaca soal jika semua anggota pada meja turnamen itu menjawab benar. Selain itu setiap kelompok meja turnamen berusaha untuk menyelesaikan tugas secara baik. Semua soal dikerjakan dan dijawab dengan baik sehingga sistem asal/gambling pada permainan di meja turnamen dapat dihindari. Kesulitan yang banyak dialami oleh kelompok meja turnamen adalah menjawab soal hitung.

\section{4) Refleksi}

Berdasarkan analisis data hasil observasi dosen dan mahasiswa, dan catatan lapangan secara umum pembelajaran dengan model pembelajaran kooperatif tipe TGT pada siklus I ini dirasa ada permasalahan untuk mahasiswa yaitu : (1) pada kegiatan permainan meja turnamen, terdapat kelompok yang tidak dapat menyelesaikan permainan dengan waktu yang telah ditentukan; (2) mahasiswa belum menyadari bahwa belajar fisika tidak hanya untuk mendapatkan produk/hasil/nilai tetapi juga untuk meningkatkan sikap, proses, dan juga aplikasi; (3) kegiatan permainan yang memberikan kesempatan bekerjasama dan mereview materi belum terbiasa dilakukan sehingga belum memberikan kemudahan; (4) belum menyadari pentingnya belajar pengertian konsep, prinsip dan rumus-rumus dengan permainan dan berkompetisi; dan (5) mahasiswa belum memaksimalkan pelaksanaan pembelajaran kooperatif dan kompetitif.

Beberapa kelemahan yang dilakukan oleh dosen dalam pembelajaran TGT pada siklus I adalah sebagai berikut : (1) dosen belum memaksimalkan informasi dan arahan sebelum pembelajaran TGT dilakukan; (2) dosen belum maksimal mengajak mahasiswa melaksanakan kesepakatan peraturan dengan baik; dan (3) dosen belum memberikan nomor pada kartu soal dan jawaban sehingga terdapat meja turnamen yang bingung saat ada jawaban yang tidak berurutan. Berdasarkan kekurangan-kekurangan dan permasalahan yang terjadi pada siklus I maka kegiatan pembelajaran pada siklus II diadakan perbaikan sebagai berikut :

a) Sebelum kegiatan dimulai dosen memberikan informasi dan arahan tentang kegiatan pembelajaran TGT, baik tujuan, fungsinya, langkah-langkah dan peraturan permainannya.

b) Mahasiswa diharapkan sudah menempatkan diri pada meja turnamen dan dosen memberi arahan langkah per langkah sehingga mahasiswa dapat melakukan peraturan yang telah disepakati dengan lebih baik. Terutama dosen perlu memberikan penjelasan lagi bahwa penjawab pertama yang benar adalah yang berhak menjadi pembaca soal/reader.

c) Dosen perlu mengulang kembali materi yang telah diajarkan pada pertemuan sebelumnya terutama pada soal hitungan.

d) Dosen perlu memberikan contoh-contoh aplikasi konsep dalam pemecahan masalah dalam kaitannya dengan penggunaan operasi matematika

e) Dosen perlu memberikan penjelasan, dan motivasi mahasiswa berkaitan dengan peraturan yang digunakan dalam pembelajaran TGT ini.

f) Dosen agar meningkatkan dan memantau kerja kelompok agar kegiatan yang dilakukan oleh mahasiswa sesuai langkah-langkah pembelajaran TGT.

g) Dosen mengklarifikasi hasil proses maupun kesimpulan melalui diskusi kelas.

\section{b. Pelaksanaan Penelitian Siklus II}

Pelaksanaan penelitian untuk siklus II untuk melanjutkan penerapan pembelajaran TGT untuk materi berikutnya yaitu statika dan dinamika fluida. Pembelajaran yang dilaksanakan dengan menggunakan model pembelajaran kooperatif tipe TGT ditingkatkan berdasarkan kelemahan atau kekurangan dari pelaksanaan siklus I.

\section{1) Perencanaan}


Tindakan yang akan dilaksanakan pada siklus II ini masih tetap seperti yang dilakukan pada tindakan siklus I yaitu pembelajaran fisika dasar dengan menggunakan TGT. Pada siklus II ini ada beberapa hal yang dilakukan untuk memperbaiki kekurangan pada siklus I. Perbaikan yang akan dilakukan pada siklus II yaitu :

a) Sebelum kegiatan dimulai dosen memberikan informasi dan arahan tentang kegiatan pembelajaran TGT, baik tujuan, fungsinya, langkah-langkah dan peraturan permainannya.

b) Mahasiswa diharapkan sudah menempatkan diri pada meja turnamen dan dosen memberi arahan langkah per langkah sehingga mahasiswa dapat melakukan peraturan yang telah disepakati dengan lebih baik. Terutama dosen perlu memberikan penjelasan lagi bahwa penjawab pertama yang benar adalah yang berhak menjadi pembaca soal/reader.

c) Dosen perlu mengulang kembali materi yang telah diajarkan pada pertemuan sebelumnya terutama pada soal hitungan.

d) Dosen perlu memberikan contoh-contoh aplikasi konsep dalam pemecahan masalah dalam kaitannya dengan penggunaan operasi matematika

e) Dosen perlu memberikan penjelasan, dan motivasi mahasiswa berkaitan dengan peraturan yang digunakan dalam pembelajaran TGT ini.

f) Dosen agar meningkatkan dan memantau kerja kelompok agar kegiatan yang dilakukan oleh mahasiswa sesuai langkah-langkah pembelajaran TGT.

g) Dosen mengklarifikasi hasil proses maupun kesimpulan melalui diskusi kelas.

Dengan adanya perubahan perbaikan dari hasil siklus I diharapkan pembelajaran akan lebih kondusif.

\section{2) Pelaksanaan Tindakan}

Kegiatan pembelajaran pada siklus II dalam pelaksanaan TGT berjalan secara kondusif. Mahasiswa setelah menerima informasi arahan tentang langkah-langkah yang harus dikerjakan mengalami perubahan dalam melaksanakannya. Mahasiswa secara sungguh-sungguh mencermati soal yang harus dikerjakan dan dijawab. Reader tidak hanya membacakan soal tetapi juga memperlihatkan soal ke anggota yang lain untuk dapat dikerjakan bersama-sama. Diskusi kelompok meja turnamen untuk memahami soal yang sulit juga telah berjalan, dalam satu meja sudah tampak sikap saling membantu, menghargai pendapat, berlapang dada, dan tidak putus asa. Mahasiswa berkompetisi dan bekerja sama dengan baik. Hal tersebut tampak pada suasana kelas yang antusias antusias, sportif dalam berkompetisi membawa kartu, dan tidak adanya mahasiswa yang diam/pasif.

Pemahaman konsep ditingkatkan dengan diskusi antar kelompok dan review materi dengan TGT mulai lebih aktif karena mahasiswa mulai menyadari bahwa kegiatan pemahaman konsep ini dirasakan sangat penting, baik secara individu, kelompok maupun dengan kompetitif. Pada kegiatan ini mahasiswa mulai banyak berfikir dan berusaha belajar dan menguasai konsep dengan permainan kelompok dan kompetitif. Mahasiswa diharapkan dapat memahami aplikasi konsep untuk situasi lain daalam bentuk pemecahan masalah atau menyelesaikan soal-soal.

\section{3) Hasil Observasi}

Hasil pengamatan siklus II oleh kolaborator dan catatan lapangan/jurnal menunjukkan bahwa dosen telah melaksanakan prosedur atau langkahlangkah pembelajaran fisika dasar dengan model pembelajaran kooperatif tipe TGT yang direncanakan. Perbaikan -perbaikan yang telah direncanakan telah dilaksanakan oleh dosen sebaik-baiknya. Pembimbingan pada kelompok-kelompok ditingkatkan, mengamati setiap kerja kelompok, diskusi yang dilakukan masing-masing kelompok.

\section{a) Aktivitas Mahasiswa}

Aktivitas mahasiswa berdasarkan pengamatan menunjukkan bahwa kagiatan ini telah terjadi perubahan-perubahan. Aktivitas kegiatan pembelajaran nampak lebih sungguh-sungguh tahapan-tahapan yang dilakukan mengarah pada kagiatan pemahaman konsep. Mahasiswa sudah mampu memahami bahwa aktivitas dalam pembelajaran ini tidak hanya untuk mendapatkan produk nilai fisika dasar akan tetapi juga peningkatan sikap mahasiswa dalam pembelajaran menjadi lebih baik seperti misalnya terdapat mahasiswa yang mau membantu anggota meja turnamen yang masih belum paham dengan jawaban pada kartu TGT, menghargai dan menerima teman yang selalu mendapatkan kartu, menerima dengan lapang dan pantang menyerah ketika belum mendapatkan kartu, mampu bersaing secara sehat dengan mematuhi aturan yang telah disepakati bersama. Selain itu, pembelajaran TGT ini juga mengajarkan mahasiswa menjadi percaya diri pada kemampuan dirinya untuk berpikir, dan belajar dari siswa yang lain. Mahasiswa mampu belajar dengan membandingkan ide/jawaban yang dimiliki dengan ide temannya, sehingga akan termotivasi untuk lebih bertanggung jawab dalam belajar, dan berpikir.

\section{b) Pemahaman Konsep}

Pada sikus I diperoleh hasil postes mahasiswa dengan klasifikasi prestasi belajar mahasiswa dapat dilihat pada gambar 1 . 


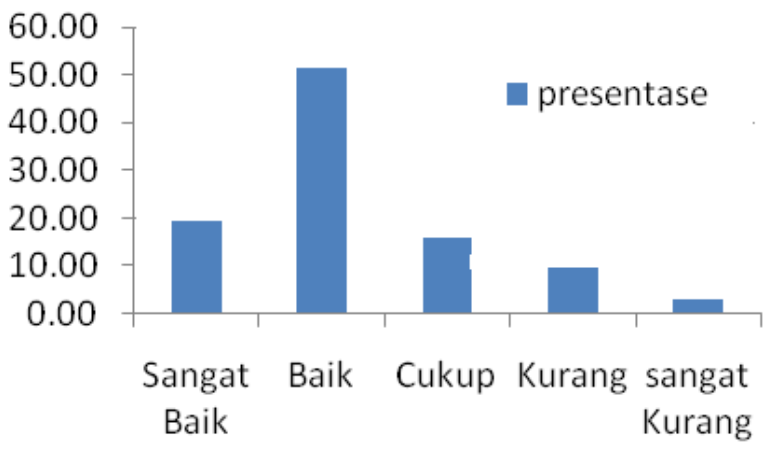

Gambar 1. Grafik Klasifikasi Mahasiswa dengan Menggunakan Model Pembelajaran Kooperatif Tipe TGT Siklus I

Berdasarkan Gambar 1 tersebut di atas menunjukkan bahwa pembelajaran menggunakan model pembelajaran kooperatif tipe TGT pada siklus I, kurang lebih 50 persen mahasiswa berada pada klasifikasi baik akan tetapi belum mencapai indikator keberhasilan penelitian ini. Berdasarkan temuan kolaborator, pemahaman konsep mahasiswa kurang baik, dan perolehan kartu pada tiap meja turnamen pada permainen tidak merata.

Dari hasil postes mahasiswa siklus II maka klasifikasi prestasi belajar mahasiswa dapat dilihat pada gambar 2 .

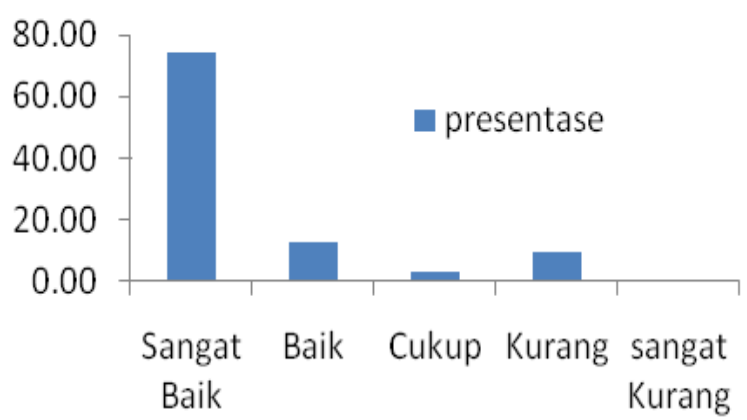

Gambar 2. Grafik Klasifikasi Mahasiswa dengan

Menggunakan Model Pembelajaran Kooperatif Tipe TGT Siklus II

Berdasarkan Gambar 2 di atas menunjukkan bahwa pembelajaran menggunakan model pembelajaran kooperatif tipe TGT pada siklus II, lebih dari 70 persen mahasiswa berada pada klasifikasi sangat baik dan sudah mencapai indikator keberhasilan penelitian ini. Berdasarkan temuan kolaborator, pemahaman konsep mahasiswa semakin baik dan mengalami peningkatan, mahasiswa sudah menikmati pembelajaran dengan permainan, kelompok dan persaingan pada meja turnamen.

\section{Pembahasan}

Berdasarkan data hasil observasi mahasiswa dan dosen telah menjalankan langkah-langkah pembelajaran TGT meliputi pembentukan kelompok, pemberian informasi TGT, membuat kesepakatan peraturan, melakukan turnamen dengan kelompok baru, dan penentuan kelompok pemenang pada siklus I. Permasalahan yang penting dalam kegiatan siklus memberikan pembiasaan kepada mahasiswa agar belajar Fisika tidak sekedar mengumpulkan pengetahuan tetapi cara kerja, cara berfikir dan memecahkan masalah. Mahasiswa diharapkan juga mengalami proses dalam belajar itu sendiri sehingga dapat mendapatkan produk berupa pemahaman konsep. Pemahaman konsep terhadap materi fisika akan menjadi sulit jika hanya dihafal saja namun perlu suatu aktivitas yang menyenangkan dan yang memerlukan aktivitas berfikir. Selain itu, mahasiswa juga diharapkan tidak mempelajari fisika dengan hanya menekankan pada produk kognitif saja, akan tetapi juga sikap ilmiah dan sikap positif lainnya.

Peningkatan partisipasi mahasiswa dapat teramati oleh peneliti dan kolaborator/observer dari pelaksanaan TGT pada tiap siklus. Perolehan skor/kartu dan atau memenangkan permainan memotivasi para pemain untuk meningkatkan permainan mereka. Sekali mereka memulai permainan, mahasiswa tidak mau berhenti sebelum permainan selesai. Mahasiswa mampu meneruskan tugas yang menjadi tanggung jawabnya di meja turnamen sehingga dapat berkontribusi bagi kelompok asal. Mereka menyelesaikan sesuai dengan waktu yang ditentukan dengan lebih teliti dan lebih baik. Hal ini menunjukkan adanya motivasi intrinsik yang berasal dari rasa tertantang, keingintahuan, ingin mendapatkan/ menguasai, ingin berkontribusi/ bermanfaat dan impian/harapan. Selain itu juga tampak keaktifan mahasiswa pada meja turnamen seperti aktif mendengarkan, respek /penghargaan/simpati dan berpikir bijaksana, berkomunikasi efektif, dan merasa dipercaya. Selain itu, keterampilan kooperatif atau partisipasi mahasiswa juga telah tampak ketika terjadinya kesepakatan peraturan TGT. Hal tersebut berarti mahasiswa dapat belajar bertanggung jawab untuk memiliki kesamaan pendapat, memahami peranan aturan dalam permainan,belajar untuk dapat menyatakan pendapat dengan cara yang sopan dan sikap yang baik, serta menghargai dan menghormati perbedaan pendapat.

Penggunaan belajar secara kompetitif dalam suasana yang konstruktif memberikan mahasiswa peraturan dan strategi untuk bersaing sebagai individu. Mereka membangun ketergantungan dan kepercayaan dalam tim asal mereka sehingga mereka merasa percaya diri dalam bersaing di meja turnamen. Hal tersebut menunjukkan bahwa mereka telah belajar untuk bersedia memikul tanggung jawab dan tugastugas/ kewajiban untuk diri sendiri dan kelompok untuk menyelesaikan tugas yang diberikan. Selain itu, mahasiswa menjadi merasa tertantang ketika melihat temannya mampu menjawab dengan benar dan berhasil membawa kartu. Semangat bersaing dengan sportif telah tampak pada tiap meja turnamen. Mahasiswa juga belajar untuk membandingkan 
jawaban dan memastikan bahwa jawaban itu benar bersama anggota meja turnamen yang lain. Hal ini menunjukkan mahasiswa menjadi semakin berkembang pemahamannya terhadap bidang studi itu serta pada meja turnamen telah berkembang hubungan yang positif antar anggota kelompoknya.

Struktur dan aturan permainan menentukan warna dan membantu sikap positif mereka. Pada penentuan pemenang, tampak mahasiswa dengan prestasi akademik rendah yang membawa lebih banyak kartu dan mahasiswa dengan prestasi akademik tinggi yang tidak dapat membawa kartu. Hal tersebut melatih mahasiswa dengan prestasi akademik tinggi untuk dapat bergembira melihat orang lain bahagia dan tidak mudah untuk meremehkan orang/mahasiswa dengan prestasi akademik rendah. Selain itu, untuk mahasiswa berprestasi akademik rendah akan lebih termotivasi dalam belajar karena merasa dirinya mampu berbuat lebih baik lagi.

Pembelajaran melalui implementasi model pembelajaran kooperatif tipe TGT ternyata dapat meningkatkan pemahaman konsep mahasiswa pada mata kuliah fisika dasar. Peningkatan pemahaman konsep mahasiswa dapat dibuktikan dari adanya peningkatan data tes mahasiswa yang dilakukan setelah tindakan. Adapun hasil postes pemahaman konsep mahasiswa tiap siklus dengan menggunakan model pembelajaran TGT dapat dilihat pada Tabel 1 di bawah ini.

Tabel 1. Data Hasil Postes Pemahaman Konsep Mahasiswa Pendidikan IPA Tiap Siklus dengan Menggunakan Model Pembelajaran Kooperatif Tipe TGT

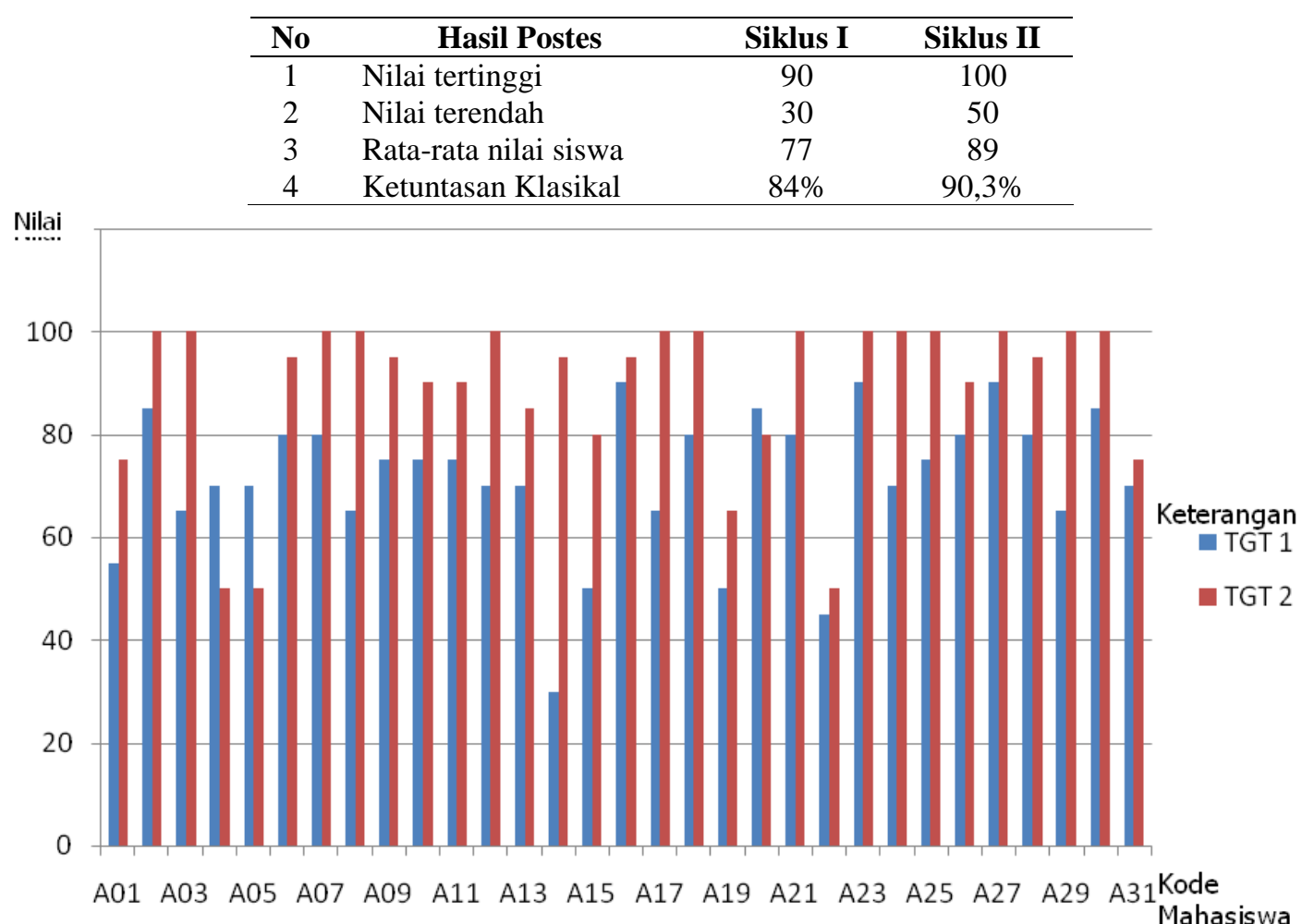

Gambar 3. Grafik tentang Pemahaman Konsep Mahasiswa Pendidikan IPA tentang Pelaksanaan Model Pembelajaran Kooperatif Tipe TGT Pada Siklus I dan II

Berdasarkan tabel 1 di atas dapat digambarkan Grafik tentang Pemahaman Konsep Mahasiswa Pendidikan IPA tentang Pelaksanaan Model Pembelajaran Kooperatif Tipe TGT Pada Siklus I dan Siklus II.

Berdasarkan Gambar 3 di atas menunjukkan bahwa pembelajaran menggunakan model pembelajaran kooperatif tipe TGT pada siklus II mengalami peningkatan. Berdasarkan temuan kolaborator, pemahaman konsep mahasiswa semakin baik dan mengalami peningkatan. Peningkatan pemahaman konsep pada siklus II terjadi karena mahasiswa terlibat langsung secara aktif dalam proses pembelajaran, dosen membantu mahasiswa yang mengalami kesulitan dalam memahami konsep materi dengan menjelaskan kembali materi yang diajarkan sebelumnya, mahasiswa sudah mulai terbiasa untuk melakukan aktivitas bermain dalam kelompok pada pembelajaran TGT, dan juga mahasiswa saling membantu kesulitan teman yang lain dalam memahami konsep. Pembelajaran dengan menggunakan permainan TGT merupakan suatu strategi yang dapat meningkatkan keterlibatan 
mahasiswa dimana kelompok-kelompok mahasiswa dapat bekerjasama dan berkompetisi mencari jawaban yang benar terhadap pertanyaan pada kartu dengan menggunakan prosedur/peraturan yang jelas. Dalam penelitian ini, kelompok-kelompok mahasiswa berusaha untuk mendapatkan kartu dan dapat memahami konsep sesuai dengan arahan dari dosen dalam melakukan pembelajaran TGT.

Partisipasi mahasiswa pada pembelajaran TGT berperan penting pada peningkatan pemahaman konsep. Belajar dengan cara berkelompok menyediakan umpan balik pada anggota kelompok yang lain dari partisipasi mereka dalam kelompok, memberikan kesempatan untuk meningkatkan keterampilan belajar kolaboratif dalam kelompok, membantu untuk menegakkan hubungan kerja yang baik diantara anggota-anggota, dan memberikan sebuah arti perayaan ketika kelompok sukses dalam belajar/permainan.

\section{KESIMPULAN DAN SARAN}

Dari hasil penelitian dan pembahasan disimpulkan bahwa pembelajaran fisika dasar dengan menggunakan model pembelajaran kooperatif tipe TGT dapat meningkatkan pemahaman konsep Fisika Dasar mahasiswa Pendidikan dan partisipasi aktif mahasiswa dalam kegiatan bermain dan aktivitas mahasiswa dalam kelompok. Pembelajaran Fisika dasar dengan menggunakan TGT terbukti dapat meningkatkan pemahaman konsep dan partisipasi aktif mahasiswa sehingga baik untuk diterapkan dalam mereview pembelajaran pada materi yang lain atau juga pada mata kuliah yang lain. Dosen perlu mengembangkan lebih lanjut implementasi model pembelajaran kooperatif tipe TGT pada materi yang lain, membiasakan kepada mahasiswa untuk berlatih belajar berkelompok/ keterampilan sosial dalam setiap kegiatan pembelajaran. Selain itu, hendaknya dosen senantiasa melakukan refleksi serta berusaha memperbaiki atau mencari pemecahan terhadap masalah yang terjadi di kelas sehingga pembelajaran yang dilakukan semakin berkualitas dan efektif.

\section{DAFTAR PUSTAKA}

[1] Robert E, Slavin. 2008. Cooperative Learning: Teori, Riset, dan Praktik. Bandung: Nusa Media.

[2] Suhaenah Suparno. 2001. Membangun Kompetensi Belajar. Jakarta: Dikti Departemen Pendidikan Nasional.

[3] Aryana, I. G. M. R., Al Idrus, A., \& Harjono, A. (2015). Pengaruh model pembelajaran kooperatif NHT dan STAD terhadap hasil belajar sikap siswa sma negeri 2 gerung. Jurnal pijar MIPA, 10(2).
[4] Raksun, A. (2009). Implementasi pembelajaran kooperatif untuk meningkatkan motivasi dan hasil belajar mahasiswa program studi pendidikan fisika fkip universitas mataram pada matakuliah biologi dasar. Jurnal pijar MIPA, 4(1).

[5] Yulianti, R., Muntari, M., \& Haris, M. (2015). Pengaruh model pembelajaran kooperatif tipe two stay two stray (tsts) dengan pendekatan brainbased learning terhadap hasil belajar kimia materi pokok struktur atom dan sistem periodik unsur pada siswa kelas $\mathrm{x}$ sman 1 kediri. Jurnal pijar MIPA, 10(1).

[6] Hirzi, R. H., Sripatmi, S., \& Hapipi, H. (2015). Penerapan model pembelajaran kooperatif tipe snowball throwing pada pembelajaran segiempat untuk meningkatkan aktivitas dan prestasi belajar siswa smpn 1 lingsar kelas vii-1 tahun pelajaran 2012/2013. Jurnal pijar MIPA, 10(1).

[7] Hikmawati, H. (2009). Implementasi modul fisika smp materi pokok gerak dengan menerapkan model pengajaran langsung dan model pembelajaran kooperatif. Jurnal pijar MIPA, 4(1).

[8] Haris, M., \& Muntari, M. (2014). Pengembangan perangkat pembelajaran kimia dengan model pembelajaran kooperatif terpadu numberd head together dan two stay two stray dalam upaya mengatasi kesulitan belajar siswa kelas x sma memahami konsep-konsep kimia. Jurnal pijar MIPA, 9(1).

[9] Micheal M van Wyk. 2010. The Effects Of Teams-Games-Tournaments On Achievement, Retention, And Attitudes Of Economics Education Students. Dublin Ireland: EABR \& ETLC Conference Proceedings 